\title{
INVESTIGATION OF THE SOURCES OF TRACHOMA IN THE WHITE SCHOOL POPULATION OF WESTERN AUSTRALIA*
}

\author{
BY \\ IDA MANN \\ Perth, Western Australia
}

IT is now nearly 6 years since the beginning of the Ophthalmic Surveys of Western Australia. During that time many thousands of school children of all races have been examined and the incidence of trachoma in the general population, white and native together, has been found to be approximately 30 per cent. If persons with aboriginal blood alone are considered, the percentage rises to 58 per cent., that in the total white population being approximately 4 per cent. These figures are derived from the results of the three Western Australian Surveys (Table I).

TABLE I

INCIDENCE OF TRACHOMA BY RACE

\begin{tabular}{|c|c|c|c|c|}
\hline Race & \multicolumn{2}{|c|}{ Area } & $\begin{array}{l}\text { No. of Persons } \\
\text { Examined }\end{array}$ & $\begin{array}{l}\text { No. Affected with } \\
\text { Trachoma }\end{array}$ \\
\hline \multirow{4}{*}{$\begin{array}{l}\text { Total } \\
\text { Persons }\end{array}$} & \multicolumn{2}{|l|}{ Kimberley } & 2,866 & 1,199 \\
\hline & \multicolumn{2}{|l|}{ Goldfields } & 2,203 & 729 \\
\hline & \multicolumn{2}{|l|}{ South-West } & 5,578 & 1,308 \\
\hline & \multicolumn{2}{|l|}{ Total } & 10,647 & $\begin{array}{c}3,236 \\
\text { (30 per cent.) }\end{array}$ \\
\hline \multirow{4}{*}{ Non-White } & Kimberley & $\begin{array}{l}\text { Coloured } \\
\text { Full-blood }\end{array}$ & $\begin{array}{r}507 \\
1,678\end{array}$ & $\begin{array}{l}225 \\
948\end{array}$ \\
\hline & Goldfields & $\begin{array}{l}\text { Coloured } \\
\text { Full-blood }\end{array}$ & $\begin{array}{l}414 \\
691\end{array}$ & $\begin{array}{l}234 \\
407\end{array}$ \\
\hline & South-West & $\begin{array}{l}\text { Coloured } \\
\text { Full-blood }\end{array}$ & $\begin{array}{r}1,793 \\
107\end{array}$ & $\begin{array}{r}1,154 \\
64\end{array}$ \\
\hline & \multicolumn{2}{|c|}{ Total with Aboriginal Blood } & 5,190 & $\begin{array}{c}3,032 \\
\text { (58 per cent.) }\end{array}$ \\
\hline \multirow{4}{*}{ White } & \multicolumn{2}{|l|}{ Kimberley } & 681 & 26 \\
\hline & \multicolumn{2}{|l|}{ Goldfields } & 1,098 & 88 \\
\hline & \multicolumn{2}{|l|}{ South-West } & 3,678 & 90 \\
\hline & \multicolumn{2}{|l|}{ Total } & 5,457 & $\begin{array}{c}204 \\
\text { (3.9 per cent.) }\end{array}$ \\
\hline
\end{tabular}

Since the preliminary surveys have been completed, repeated small local surveys have been carried out, and the impression has been gained that 
trachoma in the white population is increasing. New cases are continually being found in children by the School Medical Officers, who now make a routine examination for trachoma in every child seen. Each child is inspected at least twice during his school life.

It was therefore decided to examine some of the school findings with the intention of discovering the source of infection. This was at first naturally assumed to be by contact with non-white children, since there is no social segregation in education except that imposed by circumstances of geography and distribution of population.

It was soon apparent, however, that cases of trachoma were occurring in "all-white" schools among children in districts with no native population. The individual cases were then examined and their origins and contacts enquired into. The results are interesting, in that it becomes apparent that an exogenous as well as the expected endogenous source of infection of the white population exists. No attempt has been made to re-assess the percentage incidence in white children. This would not be easy as each school is not inspected every year, and it could be misleading, as will appear, because of the discovered existence of "pockets" of high incidence interspersed with "clean" areas.

Twenty-four schools have been considered; twelve are "all-white" schools, where the children have no contact with natives, and twelve are mixed schools. It is obvious that in the former the disease is being introduced from Italy, Jugoslavia, Greece, and other countries outside Australia, in most instances. However, pockets of the disease may exist among white Australians, left over in slum areas from the time of its former prevalence at the beginning of the century. Of 141 cases of trachoma in "all-white" schools, 96 were in children of foreign extraction and only 45 in Australians of British ancestry (Table II). Poverty, lack of hygiene, and an institutional life would seem to foster spread of the disease.

TABLE II

CHILDREN WITH TRACHOMA IN “ALL-WHITE" SCHOOLS, BY RACE

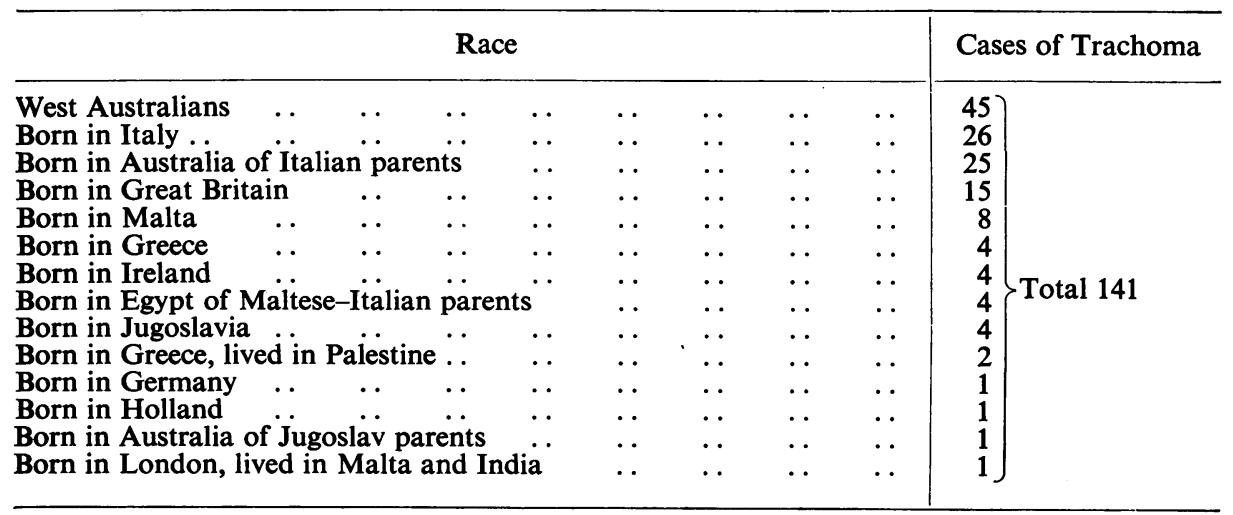


In the twelve schools with both white and native children there were always some native children, though the whites outnumbered them. In some there were foreign children, in others, none. Since the native population is known to be much more infected with trachoma than the white, we should expect the source of it in mixed schools to be from native to white. This is borne out by the figures shown in Table III. There is a much greater incidence in white Australian children in mixed schools than in white children of foreign origin.

TABLE III

CHILDREN WITH TRACHOMA IN “MIXED” SCHOOLS, BY RACE

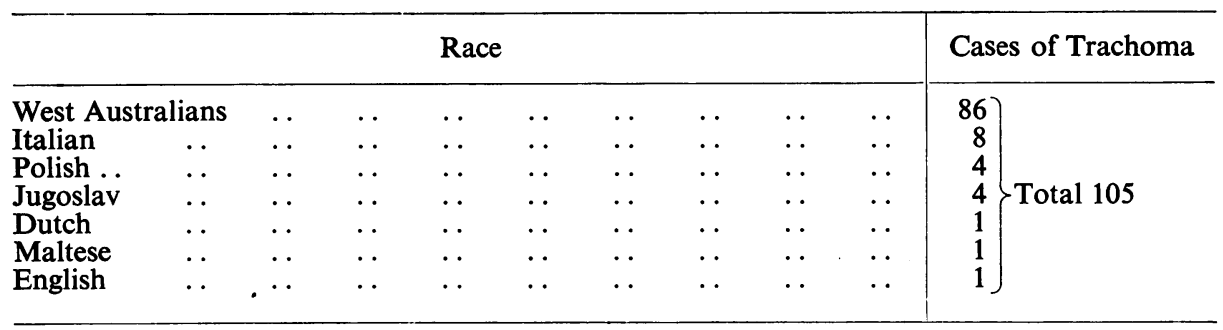

It is, however, to be remembered that, in many places, especially in the Kimberleys and the gold mining areas, there are few white persons of foreign extraction. It is therefore obvious that both sources of infection in the white population must be considered, i.e. the natives and the European immigrants. If we take all 24 schools together, we find the numbers approximately equal. Of 246 cases of trachoma in white children in 24 schools, 115 were in immigrants, mainly Italian, and 96 of these had had no native contacts.

\section{Summary and Conclusions}

Twelve schools taking only white children and twelve schools taking both white and aboriginal children were examined to find the sources of infection with trachoma in the white children.

In the "all-white" schools there were 141 cases, 96 of them in white children of foreign origin.

In the mixed schools there were 105 cases in white children, of whom only nineteen were foreign immigrants.

Therefore there are two probable sources of infection: one from native children, the other from migrants, mainly Italians, with some Poles and Jugoslavs.

In a few places, however, trachoma is still endemic in a white population with neither native nor immigrant contacts.

There is a definite danger that increased immigration is introducing trachoma into areas without native contacts which were previously free of it. 